\title{
Ultra Low Birth Weight
}

National Cancer Institute

\section{Source}

National Cancer Institute. Ultra Low Birth Weight. NCI Thesaurus. Code C114937.

Birth weight less than 750 grams. 